\title{
CONNECTIVIST LEARNING THEORY AT DEVELOPING MODERN FOREIGN LANGUAGE TEACHING MODEL
}

The article deals with the use of information and computer technologies at teaching foreign languages. The conditions of the development of the connectivist learning theory have been presented. The meanings of three learning theories behaviorism, cognitivism and constructivism that are the background of the connectivist theory have been shown.

The author defines 21st century skills, namely, cognitive competencies, intrapersonal competencies and interpersonal competencies. One of the 21st century skills is information literacy and ICT literacy. It is stated that the skill to evaluate the information becomes a meta-skill, which should be developed before the learning process begins.

The author gives the definition of connectivism that is theoretical framework for understanding learning, in which knowledge comes into action through the learner's connection to the learning community. It paves the way for a new model of learning appropriate to the knowledge-based society. The learning community is a node in the network. The character and the constituents of the network, the notion and meaning of nodes have been described. There are several factors that influence the strength of connections, e.g. motivation and influence, creation of schemes, logic and experience.

The views on connectivism of its founders George Siemens and Stephen Downes have been presented in the article. There are eight principles of connectivism by G. Siemens. The author shows the role of the teacher and the learner in the connectivist learning theory. The learning environment changes from teacher-centered into learner-centered environment.

The author shows the role of connectivist principles in the foreign language education. What does it mean to teach vocabulary in context using connectivist principles?

Key words: learning theories, digital age, connectivist learning theory, information technologies, $21^{\text {st }}$ century skills, networks, foreign language education, foreign language teaching model.

There are several learning theories that are essential for creation of the instructional environment, such as behaviorism, cognitivism and constructivism. Behaviorism assumes that we cannot possibly understand what goes on inside a person, learning is about behaviour change. Cognitivism views learning as a process of inputs, managed in short term memory, and coded for long-term recall. Constructivism suggests that learners create knowledge as they attempt to understand their experiences [1]. These theories were developed without the impact of technologies.

The current state of information system development of education is characterized by the use of a large amount of data, modern computer and multimedia technologies, video conferencing tools, virtual reality and social networking services. It is also determined by realizing not only the implementation of information and communication technologies (ICT), its social effects, the formation of information literacy of learners and teachers, but the need for teachers' continuous professional development.

Many questions are raised when established learning theories are viewed through technologies. Technologies affect not only the ways, modes, and methods of education, but what is more - the content of education. Today the lifespan of knowledge cannot be measured in decades but years, in some cases just months. As the learning conditions have been changed due to the influence of technology a new approach is needed. And here an alternative theory has been evolved - connectivist learning theory.

A lot of researchers have devoted their studies to the use of advanced technologies in language learning. Connectivist learning theory was developed by S. Downes and G. Siemens [2; 3].

Three theories are the background of the connectivist theory: 1) the theory of chaos, which states that everything is related to everything else - the role of the learner is to find and recognize hidden schemes, find senses and relationships in the seeming chaos; 2) the theory of complexity and self-organization: one of the important conditions for the development of connectivist learning theory is self-organization. George Siemens states that self-organization on a personal level is a micro-process of the larger self-organizing knowledge constructs created within corporate or institutional environments; the capacity to form connections between sources of information, and thereby create useful information patterns; 3 ) the network theory: computer networks, power grids, and social networks all function on the simple principle that people, groups, systems, nodes, entities can be connected to create an integrated whole. Connectivism is the integration of principles explored by chaos, network, and complexity and self-organization theories [3, p. 5].

The aim of our article is to analyze the role of connectivist learning theory at developing modern foreign language teaching model.

In the digital age we are surrounded in different technologies. Technology is leading to enormous changes in the economic sphere, in the way we communicate and relate to each other, and mostly in the way we learn. Kamenetz believes that in the era of almost total connectivity, of an acquisitive social media, universities must find ways of learning more transparent and fluid paths toward open source content and student-centred learning experiences [4, p. 130].

What skills are necessary for the digital age? If we are talking about the knowledge-based society, these skills are called $21^{\text {st }}$ century skills and according to the research of the National Research Council they are: 
1) cognitive competencies, which in their turn are divided into:

- cognitive processes and strategies (critical thinking, problem thinking, decision making, etc.);

- knowledge (information literacy, ICT literacy, oral and written communication, and active listening);

- creativity (creativity and innovation).

2) intrapersonal competencies:

- intellectual openness (flexibility, adaptability, personal and social responsibility, continuous learning, etc.);

- work ethic (initiative, citizenship, perseverance, etc.);

- positive core self-evaluation (self-evaluation, physical and psychological health, etc.

3) interpersonal competencies:

- teamwork and collaboration (communication, cooperation, interpersonal skills, etc.);

- leadership (responsibility, self-presentation, social influence with others) [5].

In the «networked world» [3] the skill to evaluate the information becomes a meta-skill, which should be developed before the process of learning starts.

Thus, the educational establishments must pay attention to the skills required for a knowledge-based society (the $21^{\text {st }}$ century skills) that improves the kind of learning, but now they must take into consideration another kind of learning which connects learners not only face-to-face, but also by information technology. This kind of learning can be based on connectivist learning theory.

As the founder of connectivist learning theory, George Siemens, says that connectivism blazed the trail for a new model of learning, fitted to knowledge-based society, in which learning is a process of connecting specialized nodes or information sources, because the Internet made has changed the understanding of the essence of knowledge nature [3].

One of the followers of the connectivist learning theory, Stephen Downes defines connectivism as «the thesis that knowledge is distributed across a network of connections, into its nodes, and therefore, learning consists of the ability to construct and traverse those nodes connected into networks» [6, p. 9].

According to G. Siemens, information networks contain: data (raw material); information (data with applied intelligence (the ability to store, apply, and obtain new knowledge); knowledge (knowledge in a context); and meaning (understanding of values, implication of knowledge) [3].

What are nodes? There are a lot of connections, links between entities in the network, which can be named nodes and each node has information as forms of knowledge. A node can include a person, a group of people, a computer or ideas and communities. In other words, a node is a learning community. A network comprises several nodes, connected for sharing information. Nodes can be of different size, depending of the amount of information and a number of entities, working in a particular node. If we change data in a node, the data is changed in another node. Being connected into a network, the nodes play their role in sharing the information which can be transformed in true knowledge.

Connections between nodes are representations of knowledge and understanding. Learning in connectivism is actionable knowledge. Learners use the ties between nodes, recognize the patterns, connect to the small world of individual knowledge and extend personal network. G. Siemens and S. Downes conclude that in connectivism knowledge is shared between nodes of knowledge, which are individuals or organizations. Knowledge can be stored in various formats. It can be found in two domains: cognitive and affective. These two domains greatly contribute the learning process.

There are factors that influence the strength of connections [3]:

- motivation (influenced by emotions and logic);

- influence (repetition);

- creation of schemes (recognition of the substance and organization of various types of information and knowledge);

- logic (organization and structuring of networks);

- experience (booster of obtaining new nodes and formation of new connections among the old ones).

As the information is constantly changing connectivism focuses on the two important skills, in particular, the ability to search the relevant and current information and the ability to filter secondary and unnecessary information.

According to S. Downes there are three perspectives that connectivism is described from. These perspectives are presented as a cycle. They are: 1) knowledge informs learning; 2) what we learn informs community; 3) the community creates knowledge. And in the reverse order: 1) knowledge builds community;2) community defines what is learned; 3) what is learned becomes community [6, p. 15].

George Siemens presents the principles of connectivism:

- Learning and knowledge rests in diversity of opinions.

- Learning is a process of connecting specialized nodes or information sources.

- Learning may reside in non-human appliances.

- Capacity to know more is more critical than what is currently known.

- Nurturing and maintaining connections is needed to facilitate continual learning.

- Ability to see connections between fields, ideas, and concepts is a core skill.

- Currency (accurate, up-to-date knowledge) is the intent of all connectivist learning activities. 
- Decision-making is itself a learning process. Choosing what to learn and the meaning of incoming information is seen through the lens of a shifting reality $[3, \mathrm{p} .6]$.

Developers of e-learning (G. Siemens) believe that the influence of the Internet and online connectedness of people will have implications for educational practice. The rapid development of technology and growth in the use of the Internet, along with mobile developments, make new and different educational structures, institutions and more opportunities. The online and face-to-face networks that people build throughout their lives will provide knowledge. Learners will be at the centre of the learning experience, rather than the teacher and the establishment. Learners will be of the essence in determining the content of the learning, in addition to deciding the character and level of communication.

Rita Kop and Adrian Hill think that the role of the teacher will not only change, but may disappear. People can replace a learning environment controlled by the teacher and the institution to an environment where they direct their own learning, find their own information, and create knowledge by engaging in networks away from the formal education. They still communicate with others, but their personal interests and preferences are the main drivers for their engagement with more knowledgeable others in their learning [7].

The problem of applying the connectivist learning theory in foreign language education has been discussed mainly among practicing teachers. They share their ideas and experience on the internet discussions. However, they discuss mainly the link between the learner and the great amount of information and draw attention to the capacity of the Internet and social networks (e.g. Facebook, Twitter), communication technologies (e.g. Skype, Zoom), and highlight the possibility of creating networks of foreign language teachers by the means of blogs or discussion groups.

Katerina Veselá suggests that the potential of connectivist principles in foreign language education is much higher. The researcher believes that foreign language education should be according to the connectivist principles based on understanding the system. It is important for learners to be able to perceive a language not as a structure, but as a network of networks (the network of morphology connected with the networks of syntax, lexicology, and phonology together create a network connected with the network of semantics), and then to comprehend the connections among the nodes within these networks [8].

According the factors that influence the strength of connections the effectiveness of learning a foreign language depends on:

- motivation (why I want to learn the foreign language);

- influence (we remember a word or a phrase when we repeat it eight times at average);

- creation of schemes (recognition of the language schemes and functions);

- logic (organization and structuring of language networks);

- experience (obtaining new nodes and formation of new connections among the them, practical use).

In foreign language education it is essential to decode, interpret, understand and connect a new node with the old ones. If we have to teach vocabulary, we should teach it in context. And here we can apple the cognitive and affective domains - cognition (using different examples for explanation), emotions (learning by songs, poems, drama).

If we refer to the connectivist principles mentioned above, we also can notice the connection between teaching a foreign language and connectivist learning theory:

1. Learning and knowledge rests in diversity of opinions (there are diverse meanings of words, phrases in a language in various context as well as different language variants).

2. Learning is a process of connecting specialized nodes or information sources (in teaching a foreign language it is important to use a variety of information resources).

3. Learning may reside in non-human appliances (e-learning uses the systems for education that work without a human interference).

4. Capacity to know more is more critical than what is currently known (foreign language learning is a long-life activity).

5. Nurturing and maintaining connections is needed to facilitate continual learning (it is necessary to maintain and update the old nodes and create the new ones).

6. Ability to see connections between fields, ideas, and concepts is a core skill (a foreign language is learnt not just as a group of words and phrases, it is necessary to see the connections among the language networks).

7. Currency is the intent of all connectivist learning activities (it is essential to use the current resources as the English language is constantly changing under the influence of modern technologies).

8. Decision-making is itself a learning process (choice is the important factor of the foreign language education. The learner can decide not only about the language they learn, but also, for example what field to choose in the case of learning a foreign language for specific purposes).

Conclusions. To sum it up, in the digital era connectivism plays an important role in the development of new pedagogies, where we can observe the shift from the teacher to an autonomous learner. Connectivism provides comprehension of learning skills and tasks needed for learners to develop. The connectivist principles worked out by $\mathrm{G}$. Siemens can be used for teaching a foreign language.

Thus, we believe that nowadays when the conditions of studying have been changed from offline to online learning, an English language teacher has to pay attention to the principles of connectivist learning theory that emphasizes the contribution of the Internet technologies to the new perspectives of teaching and learning. 
Bibliography:

1. Driscoll Marcy Perkins. Psychology of Learning for Instruction. $3^{\text {nd }}$ edition. Boston : Allyn \& Bacon, 2005. 476 p.

2. Downes Stephen. Places to Go: Connectivism \& Connective Knowledge. Innovate: Journal of Online Education. Vol. 5. Issue 1. 2008. Article 6.

3. Siemens George. Connectivism: A Learning Theory for the Digital Age. International Journal of Instructional Technology and Distance Learning. No. 2 (1). 2005. URL: http://www.itdl.org/Journal/Jan_05/article01.htm.

4. Kamenetz Anya. DIY U: Edupunks, edupreneurs, and the coming transformation of higher education. White River Junction, VT: Chelsea Green Publishing, 2010. 196 p.

5. National Academies of Science, National Research Council. Education for Life and Work: Developing Transferable Knowledge and Skills in the 21st Century. Washington, DC : National Academies Press, 2012. 256 p.

6. Downes Stephen. Connectivism and connective knowledge. Essays on meaning and learning networks. National Research Council Canada, 2012. 616 p.

7. Kop Rita and Hill Adrian. Connectivism: Learning theory of the future or vestige of the past? International Review of Research in Open and Distance Learning, Vol. 9, No 3. 2008. Pp. 1-13.

8. Veselá Katerina. Connectivism in Foreign Language Education. Education and Languages in Europe, Vol. 25, No. 17. 2013. Pp. 320-325.

\section{References:}

1. Driscoll Marcy Perkins. (2005) Psychology of Learning for Instruction. $3^{\text {nd }}$ edition. Boston: Allyn \& Bacon. 476 p.

2. Downes Stephen. (2008) Places to Go: Connectivism \& Connective Knowledge. Innovate: Journal of Online Education. Vol. 5. Issue 1. Article 6.

3. Siemens George. (2005) Connectivism: A Learning Theory for the Digital Age. International Journal of Instructional Technology and Distance Learning. 2 (1). Retrieved from: http://www.itdl.org/Journal/Jan_05/article01.htm.

4. Kamenetz Anya. (2010) DIY U: Edupunks, edupreneurs, and the coming transformation of higher education. White River Junction, VT: Chelsea Green Publishing.196 p.

5. National Academies of Science, National Research Council. Education for Life and Work: Developing Transferable Knowledge and Skills in the 21st Century. Washington, DC: National Academies Press, 2012. 256 p.

6. Downes Stephen. (2012) Connectivism and connective knowledge. Essays on meaning and learning networks. National Research Council Canada. 616 p.

7. Kop Rita and Hill Adrian. (2008) Connectivism: Learning theory of the future or vestige of the past? International Review of Research in Open and Distance Learning, Vol. 9, No 3. P. 1-13.

8. Veselá Katerina. (2013) Connectivism in Foreign Language Education. Education and Languages in Europe, Vol. 25, No. 17. P. $320-325$.

\section{Гандабура О. В. Теорія конективізму в процесі створення сучасної моделі навчання іноземних мов}

Стаття присвячена використанню інформачійних та комп 'ютерних технологій під час викладання іноземних мов. Представлено умови розвитку конективістської теорії навчання. Продемонстровано значення трьох теорій навчання біхевіоризму, когнітивізму та конструктивізму, які є основою для теорії конективізму.

Автор визначає навички XХI століття, а саме когнітивні компетентності, внутрішньоособистісні та міжособистісні компетентності. Однією з навичок XXI століття є інформаційна та IКТ-грамотність. Зазначається, щзо вміння оцінювати інформацію стає мета-вмінням, яке слід розвивати до початку процесу навчання.

Автор дає визначення конективізму, а саме конективізм - ие теоретична база для розуміння навчання, в якій знання активуються через зв'язок учня з навчальною спільнотою. Це відкриває шлях до нової моделі навчання, яка підходить для суспільства, яке використовує засоби та методи штучного інтелекту. Навчальна спільнота - ие вузол у мережі. Описано характер та складники поняття «мережа», поняття та значення вузлів. $C$ кілька факторів, щзо впливають на міиність зв'язків, наприклад, мотивація та вплив, створення схем, логіка та досвід.

У статті представлені погляди на конективізм його засновників Джорджа Сіменса та Стівена Даунса. $С$ вісім приниипів конективістської теорії навчання за Дж. Сіменсом. Автор показує роль викладача та учня в теорії конективізму. Навчальне середовище змінюється від середовища, яке орієнтоване на вчителя, на середовище, яке орієнтоване на учня.

Автор показує роль принципів конективізму у навчанні іноземних мов. Зв'язок вивчення іноземних мов та теорії конективізму не обмежується лише використанням інформаційних технологій. Що означає викладати лексику в контексті, використовуючи принципи конективізму? Для студентів важливо відчувати мову не як структуру, а як мережу.

Ключові слова: теорї навчання, ицфрова епоха, конективістська теорія навчання, інформаційні технології, навички XXI століття, мережі, вивчення іноземних мов, модель навчання іноземних мов. 